19 Revue d'histoire du XIXe siècle

Société d'histoire de la révolution de 1848 et des

révolutions du XIXe siècle

17 | 1998

Les foules au XIXe siècle

\title{
Hommage à Mirella Larizza-Lolli
}

Jean-Claude Caron and Jacqueline Lalouette

URL: http://journals.openedition.org/rh19/143

DOI: $10.4000 /$ rh 19.143

ISSN: $1777-5329$

Publisher

La Société de 1848

Printed version

Date of publication: 1 December 1998

ISSN: 1265-1354

Electronic reference

Jean-Claude Caron and Jacqueline Lalouette, « Hommage à Mirella Larizza-Lolli », Revue d'histoire du XIXe siècle [Online], 17| 1998, Online since 10 September 2008, connection on 21 April 2019. URL http://journals.openedition.org/rh19/143; DOI : 10.4000/rh19.143

This text was automatically generated on 21 April 2019

Tous droits réservés 


\section{Hommage à Mirella Larizza-Lolli}

Jean-Claude Caron and Jacqueline Lalouette

\section{ABSTRACTS}

No abstract available by now

Pas de résumé disponible actuellement

INDEX

Mots-clés: Hommage, Larizza-Lolli Mirella 